Available online at GSC Online Press Directory

GSC Biological and Pharmaceutical Sciences

e-ISSN: 2581-3250, CODEN (USA): GBPSC2

Journal homepage: https://www.gsconlinepress.com/journals/gscbps

(RESEARCH ARTICLE)

\title{
Performance and haematology of broiler strains (cobbs and arbor-acre) fed ginger (Zingiber officinale) based diet at the early phase
}

\author{
Iyaode Iyekeji Ifelayo, Oyewole Benjamin Osigbodi*, Adesola Mercy Adetola and Anjorin Grace Oluwabunmi
}

Department of Animal Production, Kogi State University, Anyigba, Nigeria.

Publication history: Received on 18 April 2020; revised on 25 April 2020; accepted on 28 April 2020

Article DOI: https://doi.org/10.30574/gscbps.2020.11.1.0107

\begin{abstract}
The research was conducted to evaluate the performance and haematology of broiler strains (Cobbs and Arbor-acre) fed ginger (Zingiber officinale) at the early phase. A total of one hundred and forty-four (144) day old chicks of mixed sexes comprising of two different strains were used for the experiment. They were randomly assigned to the three different experimental treatment groups. Treatment 1 ( T1 = basal diet only); Treatment 2 (T2 = basal diet $+0.5 \%$ ginger); Treatment 3 (T3 = basal diet $+1.0 \%$ ginger). Each treatment group was replicated three (3) times in a Completely Randomized Design (CRD). Results showed that ginger inclusion caused significant $(p<0.05)$ increase on final weight, weight gain, daily weight gain and feed conversion ratio, as better performance was recorded with the increase in the inclusion level of ginger. Final weight, weight gain, daily weight gains and feed conversion ratio was significantly affected by strain treatment interaction at $0.5 \%$ ginger inclusion as theCobbs strain had a higher performance than the Arbor acre strain. The effect of dietary levels of ginger (Zingiber officinale) on the haematology of different strains of broiler showed that ginger inclusion significantly increased $(p<0.05)$ all the haematological parameters evaluated except for PCV. It is observed that there were better haematological indices for Cobbs strain, and better response at 1\% ginger inclusion. Inclusion of ginger (at 1\%) favoured the performance and haematological indices of broiler chickens.
\end{abstract}

Keywords: Performance; Haematology; Broiler; Strains; Ginger

\section{Introduction}

Nutrition is the most expensive factor in poultry production taking approximately $70 \%$ of production budgets [1; 2]. Therefore, to reduce the cost of production, improvement in the feed efficiency would be a feasible option. The use of feed additives as growth promoters in poultry nutrition is one of the ways to accomplish this goal.

Growth promoters are commonly used to stimulate growth and protect the health of poultry [3]. Among growth promoters, the most commonly used are antibiotics. However, their use is restricted due to possible development of drug resistance in bacteria, drug residue in carcass and also alteration of natural gut micro flora [4]. Many countries tend to minimize or prohibit the use of antibiotics because of their deleterious side effects on both animals and humans. Recently, studies have become more focused on the use of naturally occurring phytobiotics to replace the chemically based feed additives [5]. Phytogenics are a group of natural growth promoters or non-antibiotic growth promoters, derived from herbs, spices or other plants, which have been reported to possess antimicrobial, anti-oxidative, antiinflammatory and immuno-modulatory properties [6]. The positive effects of herbal supplements on broiler performance, carcass quality and quality traits of meat have been demonstrated [7].

\footnotetext{
${ }^{*}$ Corresponding author: Oyewole Benjamin Osigbodi
} 
There are several naturally existing herbs (medicinal plants) which could be used in preventing the accumulation of lipids including neutral fats and cholesterol, prominent among these plants is ginger (Zingiber officinale). Ginger has gained prominence due to its wide range of properties not only in reducing lipids but, in many other ways where the utmost aim is to improve the nutritive value of the animal products (meat, milk or egg) [8].

Information obtained from haematological assay, apart from being useful for diagnostic and management purposes could equally be incorporated into breeding programs [9]. Haematological studies are of ecological and physiological interest in helping to understand the relationship of blood characteristic to the environment and so could be useful in the selection of animals that are genetically resistant to certain diseases and environmental conditions [10]. Haematological parameters are good indicators of the physiological status of animals [11], and are related to the blood and blood forming organs [12]. The examination of blood gives the opportunity to investigate the presence of several metabolites and other constituents in the body of animals and plays a vital role in the physiological, nutritional and pathological status of an organism [13].

\subsection{Justification of the study}

The search for natural feed additives which have no adverse effect on the performance and health of animals continues to attract the attention of researchers in developing countries, achieving this through dietary inclusion of naturally occurring herbs may be a cheap and safe way, and amenable to increased adoption by poultry farmers.

\subsection{Objective of the study}

The feeding trial sought to investigate the effect of graded levels of ginger inclusion on the performance and haematological indices of two broiler strains at the early phase.

\section{Materials and methods}

The experiment was carried out at the Poultry Unit of the Kogi State University Livestock Teaching and Research Farm, Anyigba, Kogi State. Anyigba is located in the derived savannah zone of Nigeria on latitude $7^{\circ} 30^{\prime} \mathrm{N}$ and longitude $7^{\circ}$ $09^{\prime} \mathrm{E}$. The zone is characterized by 6-7 months of annual rainfall ranging from $1400-1500 \mathrm{~mm}$ and day temperature range of $25^{\circ} \mathrm{C}-35^{\circ} \mathrm{C}$ with the highest temperature in March and April [14].

Fresh ginger (Zingiber officinale) was purchased, washed, peeled, chopped into smaller pieces, dried andground into powder. Ginger powder was incorporated into the experimental diet for cobbs and arbor acre at $0 \%, 0.5 \%$ and $1 \%$ as the various treatments respectively. The experimental basal diet was formulated with a crude protein of $23 \%$.

A total of one hundred and forty-four (144) day old chicks of mixed sexes comprising of two different strains (Arbor acre and Cobbs) were randomly assigned to the three different experimental treatment groups. Treatment 1 (T1 = basal diet only); Treatment 2 (T2 = basal diet $+0.5 \%$ ginger); Treatment 3 (T3 = basal diet $+1.0 \%$ ginger). Each of the treatment groups per strain was replicated three (3) times with eight (8) chicks per replicate.

\subsection{Management of birds}

All the necessary management practices for broiler chickens, such as brooding, vaccinations, feeding, sanitation, record keeping and medication were strictly adhered to.

\subsection{Data collection/ method of collection}

Data collected were feed intake and efficiency, body weight gain, haematological parameters [packed cell volume (PCV), red blood cell count (RBC), white blood cell (WBC), haemoglobin, mean corpuscular haemoglobin (MCH), mean corpuscular concentration (MCHC) and platelets].The duration of the experiment was four weeks.

\subsection{Statistical analysis}

Data collected in the course of the experiment were subjected to Analysis of Variance (ANOVA) as appropriate for a 2x3 factorial arrangement implemented within the Completely Randomized Design (CRD) using Statistical Package for Social Sciences (SPSS version 20). Significant means were separated using LSD at 5\% level of significance. 


\section{Results and discussion}

Table 1 Effect of strain on the performance and haematology of broiler fed ginger

\begin{tabular}{llll}
\hline Parameter & Cobbs & Arbor acre & LOS \\
\hline Initial weight (g) & $40.11 \pm 0.20$ & $39.92 \pm 0.20$ & NS \\
Final weight(g) & $582.89 \pm 10.96$ & $578.78 \pm 10.96$ & NS \\
Weight difference(g) & $543.21 \pm 10.07$ & $539.29 \pm 10.07$ & NS \\
Daily weight gain(g) & $19.40 \pm 0.39$ & $19.26 \pm 0.39$ & NS \\
Daily feed intake(g) & $67.18 \pm 0.92$ & $68.00 \pm 0.92$ & NS \\
Feed conversion ratio & $3.46 \pm 0.58$ & $3.53 \pm 0.58$ & NS \\
PCV (\%) & 29.00 & 29.20 & NS \\
HB (g/dL) & 9.91 & 10.09 & NS \\
WBC (x10 $/ \mathrm{L})$ & 224.56 & 209.62 & NS \\
RBC (x10 $12 / L)$ & $2.46^{\mathrm{b}}$ & $2.48^{\mathrm{a}}$ & $*$ \\
MCV (fl) & 133.06 & 131.15 & NS \\
MCH (pg) & 45.78 & 44.60 & NS \\
MCHC (g/dL) & 34.11 & 33.70 & NS \\
Neutrophil (x10 $/ \mathrm{L})$ & 4.94 & 4.20 & NS \\
Lymphocyte (x10 $/ \mathrm{L})$ & 96.44 & 96.37 & NS
\end{tabular}

$\mathrm{abc}=$ means with different superscript along the same row show significant difference at $\mathrm{p}<0.05$, LOS= level of significance, PCV = Pack Cell Volume, $\mathrm{HB}=$ haemoglobin, WBC = White Blood Cell, RBC = Red Blood Cell, MCV = Mean Cell Volume, MCH = Mean Corpuscular Haemoglobin, MCHC = Mean Corpuscular Haemoglobin Concentration, SEM = Standard Error of the Mean, NS = no significant difference, LOS = Level of Significance, FCR= feed conversion ratio, ${ }^{*}=$ significantly different.

Result obtained in Table 1 showed that strain had no significant influence $(p>0.05)$ on the performance characteristics and haematological indices of the birds except for RBC that showed that the Arbor acre strain was significantly $(\mathrm{p}<0.05)$ higher than the Cobbs strain. However, cobbs strain showed higher numeric values for initial weight, final weight, weight difference, daily weight gain and feed conversion ratio but the Arbor acre strain showed higher values for the daily feed intake.

The non-significant difference $(\mathrm{P}<0.05)$ in body weight gain of the strains is an indication that the genetic trait variation between strain is not significant. This is in contrast with reports by Deeb and Lamont [15] who reported that genetic differences existed among broiler strains and these differences bring about differences in their performance [16]. The genetic variation between the two strains is not significant in terms of feed consumption and their different nutrient requirement, since birds eat to satisfy their nutritional needs [17]. The higher feed intake of Arbor acre strain on the other hand though not significant $(\mathrm{p}<0.05)$ is an indication of a higher energy requirement as compared to the cobbs strains [18]. It is reasonable to infer that limiting their feed intake by any means therefore would drastically affect the performance Arbor acre strain with less effect on the cobbs strain which is a product of their genetic make-up [19]. The low feed consumption and the high feed conversion ratio indicates superiority of the cobbs strain to Arbor acre. [20; 21] stated that the body weight gain, feed consumed and feed conversion ratio are all affected by specific physiological demands at specific age. This determines maintenance energy requirement, feed intake, feed conversion ratio and the ultimate body weight gain. This could imply that at four (4) weeks the physiological need of the different strain of birds were basically the same.

The values for haematological indices obtained in Table 1 though significantly different $(\mathrm{p}<0.05)$ correspond with normal ranges reported by Oladipo et al. [22] except for the WBC. [22] reported a range of $27.67 \%-30.00 \%, 2.95 \times 10^{6} / 1$ - $3.52 \times 10^{6} / \mathrm{l}, 13.10 \times 10^{6} / \mathrm{l}-5.67 \times 10^{6} / \mathrm{l}$ for PCV, WBC and RBC respectively. Oguntoye [23] reported values range of 26.50-32.50, 8.93-10.45, 3.08-3.53, and 3.53-3.8 for PCV, HB, WBC and RBC respectively as normal ranges for broiler. Observed results show Cobbs having significantly higher $(\mathrm{p}<0.05)$ RBC parameter. Red blood cell count observed in this 
study for Arbor acre and Cobbs broiler strains contrasted to some extent among themselves showing variation that exist among genetically related strains [24], however, [25] observed variation in haematological profile of different strains.

Table 2 Effect of varied inclusion level of ginger on the performance of broiler across treatment groups

\begin{tabular}{lllll}
\hline Parameters & T1 (0\%) & T2 (0.5\%) & T3 (1.0\%) & LOS \\
\hline Initial weight (g) & $39.92 \pm 0.17$ & $39.64 \pm 0.17$ & $39.73 \pm 0.17$ & NS \\
Final weight (g) & $499.83 \mathrm{c} \pm 13.42$ & $601.33 \mathrm{~b} \pm 13.42$ & $641.33 \mathrm{a} \pm 13.42$ & $*$ \\
Weight difference (g) & $460.35 \mathrm{c} \pm 13.40$ & $561.53 \mathrm{~b} \pm 13.40$ & $601.87 \mathrm{a} \pm 13.40$ & $*$ \\
Daily weight gain (g) & $16.44 \mathrm{c} \pm 0.48$ & $20.06 \mathrm{~b} \pm 0.48$ & $21.49 \mathrm{a} \pm 0.48$ & $*$ \\
Daily feed intake (g) & $65.97 \mathrm{~b} \pm 1.13$ & $66.15 \mathrm{~b} \pm 1.13$ & $70.66 \mathrm{a} \pm 1.13$ & $*$ \\
Feed conversion ratio & $4.01 \mathrm{~b} \pm 0.71$ & $3.30 \mathrm{a} \pm 0.71$ & $3.29 \mathrm{a} \pm 0.71$ & $*$ \\
\hline $\mathrm{abc}=$ means with different superscript along the same rows show significant different at $(\mathrm{p}<0.05)$, Los $=$ level of significance, NS = not significant,
\end{tabular}

Table 2 shows that performance parameters were significantly $(\mathrm{p}<0.05)$ affected by treatment effect except for the initial weight with a range value of $39.64 \mathrm{~g} \pm 0.17$ to $39.92 \mathrm{~g} \pm 0.17$. The non-significant difference obtained implies that birds of both strains were evenly randomized thereby avoiding bias among treatments. Final weight however showed significantly higher value $(\mathrm{p}<0.05)$ for T3 $(641.33 \pm 13.42)$. Value of final weight across treatment means appear to increase with increasing inclusion level of ginger. Value range of 499.83 to $641.13 \mathrm{~g} \pm 13.42$ was obtained. Increase in the final weight across treatment groups imply that increase in weight was stimulated by increasing the inclusion level of ginger root meal. Observed result was synonymous with [26] who reported a steady increase in weight gain for birds whose diets were supplemented with ginger. [27] suggested that gingerol's anti-microbial activity promotes the performance of the intestinal flora thereby improving digestion and enhancing the utilization of energy, leading to improved growth. Weight gain shows the actual gain due the treatment effect. Obtained results show significant difference $(\mathrm{p}<0.05)$ across treatments with increased inclusion level of ginger root meal. Value range of $460.35 \pm 13.40$ to $601.87 \pm 13.40$ was obtained for weight gain. Observations were in line with [28] who reported weight differences which were significantly higher with birds on ginger supplemented diets. [29] reported higher weight gain for ginger root infusion than powder. [30] however, reported a negative trend when inclusion levels reached $3 \%$ as gastric irritation, dyspepsin, diarrhea, eructation and mortality resulted due to excessive inclusion.

Daily weight gains followed similar trend. Result shows significant difference $(\mathrm{p}<0.05)$ across treatment means with increasing ginger inclusion level. Highest significant $(\mathrm{p}<0.05)$ daily weight gain was obtained in T3 $(21.49 \mathrm{~g} \pm 0.48)$. Value range of $16.44 \mathrm{~g} \pm 0.48$ to $21.49 \mathrm{~g} \pm 0.48$ was obtained for the control group and $1 \%$ ginger root meal. Results obtains confirms the findings of $[31 ; 32]$ who fed herbal plants (ginger and garlic) as growth promoters in broiler diets and observed a significant improvement $(\mathrm{p}<0.05)$ in their body weight gain and feed conversion ratio.

The daily feed intake of birds in T1 (65.97 \pm 1.13$)$ and $\mathrm{T} 2(66.15 \mathrm{~g} \pm 31.13)$ were similar and significantly lower that T3 (70.66g \pm 1.3$)$. Intake increased as the level of ginger supplementation in the diet increased. This indicates that ginger increase appetite and digestion by stimulation digestive juice such as bile, saliva, gastric, pancreatic and intestinal secretion [33]. Value recorded in this research was in line with reports of [34]. [35; 36] however, reported that ginger powder had no significant effect on the intake of the birds. [37] work on the proven effects of phytobiotic feed additives in different poultry species, indicated a reduced feed intake, and improved feed conversion ratio for all species of birds.

Birds fed diets with ginger root meal had a significantly better $(\mathrm{p}<0.05)$ feed conversion ratio than those on the control diet. Invariably birds with higher feed conversion ratio had higher final body weight gain. Similar, observations were made by [38], in their study on weaned rabbits, they noted that these herbs addictive may have controlled and limited the growth and colonization of numerous pathogenic and non-pathogenic species of bacteria in the GIT leading to improved conversion of feed to meat. [39] also suggested that ginger supplementation enhances the activity of pancreatic enzymes and provides an environment for better absorption of nutrients. 
Iyaode et al. / GSC Biological and Pharmaceutical Sciences, 2020, 11(01), 197-206

Table 3 Treatment effect on the haematology of broiler chickens fed ginger (Zingiber officinale).

\begin{tabular}{llllll}
\hline Parameters & T1 (0\%) & T2 (0.5\%) & T3 (1\%) & SEM & LOS \\
\hline PCV (\%) & 28.75 & 29.33 & 29.18 & 0.41 & NS \\
HB (g/dL) & $9.43^{\mathrm{c}}$ & $10.03^{\mathrm{b}}$ & $10.50^{\mathrm{a}}$ & 0.16 & $*$ \\
WBC (x109/L) & $212.42^{\mathrm{ab}}$ & $206.15^{\mathrm{b}}$ & $232.82^{\mathrm{a}}$ & 10.85 & $*$ \\
RBC (x1012/L) & $2.39^{\mathrm{b}}$ & $2.49^{\mathrm{a}}$ & $2.52^{\mathrm{a}}$ & 0.02 & $*$ \\
MCV (fl) & $126.43^{\mathrm{b}}$ & $131.36^{\mathrm{b}}$ & $138.65^{\mathrm{a}}$ & 3.00 & $*$ \\
MCH (pg) & $42.44^{\mathrm{c}}$ & $44.98^{\mathrm{b}}$ & $48.19^{\mathrm{a}}$ & 1.07 & $*$ \\
MCHC (g/dL) & $33.55^{\mathrm{b}}$ & $34.00^{\mathrm{b}}$ & $34.18^{\mathrm{a}}$ & 0.31 & $*$ \\
Neutrophil (x109/L) & $3.50^{\mathrm{b}}$ & $4.58^{\mathrm{ab}}$ & $5.64^{\mathrm{a}}$ & 0.60 & $*$ \\
Lymphocyte (x109/L) & $95.67^{\mathrm{b}}$ & $96.55^{\mathrm{ab}}$ & $97.00^{\mathrm{a}}$ & 0.61 & $*$
\end{tabular}

$\mathrm{abc}=$ Means with different superscripts along the same row showing significant difference at $\mathrm{p}<0.05, \mathrm{PCV}=\mathrm{Pack}$ Cell Volume, $\mathrm{HB}=\mathrm{haemogl}$ obin WBC $=$ White Blood Cell, RBC = Red Blood Cell, MCV = Mean Cell Volume, $\mathrm{MCH}=$ Mean Corpuscular Haemoglobin, $\mathrm{MCHC}=\mathrm{Mean}$ Corpuscular Haemoglobin Concentration, SEM = Standard Error of the Mean, NS = no significant difference, LOS = Level of Significance, T1 $0 \%$ ) $=$ Treatment 1 of Basal diet, $\mathrm{T} 2(0.5 \%)=$ Treatment 2 containing $0.5 \%$ ginger and $\mathrm{T} 3(1.0 \%)=$ Treatment 3 containing $1.0 \%$ ginger.

Table 3 shows that pack cell volume had no significant difference ( $>0.05)$ across treatments but birds in T2 (ginger $0.5 \%)$ showed the highest numerical value (29.33). However, there were significant differences $(\mathrm{p}<0.05)$ observed across all other haematological indices with treatment $\mathrm{T} 3$ showing the highest level of significance across the treatment groups. Haematological indices for PCV, though significantly different $(\mathrm{p}<0.05)$ among treatments, the range of 28.75 $29.33 \%$ is within the normal values reported by [23]. According to [40], packed cell volume is involved in the transport of oxygen and absorbed nutrients. Increased packed cell volume shows better transportation and thus results in an increased primary and secondary polycythemia. PCV beyond the normal range is an indicator of toxic factors which could have adverse effect on the formation of blood [41].There was significant difference $(\mathrm{p}<0.05)$ for haemoglobin, observed result showed T3 $(10.50 \mathrm{~g} / \mathrm{dl})$ being significantly higher than the rest treatment means. Value range of haemoglobin observed was $9.43 \mathrm{~g} / \mathrm{dl}-10.50 \mathrm{~g} / \mathrm{dl}$. White blood cell value though significantly different $(\mathrm{p}<0.05)$ among treatment means, did not follow a particular order. Diet T3 had the highest value of 232.82, while T2 (206.15) had the least value. The range observed WBC (206.15 - 232.82), falls within the range for normal birds [42]. The major functions of the white blood cell and its differentials are to fight infections, defend the body by phagocytocis against invasion by foreign organisms and to produce or at least transport and distribute antibodies in immune response. Thus, animals with low white blood cells are exposed to high risk of disease infection, while those with high counts are capable of generating antibodies in the process of phagocytosis and have high degree of resistance to diseases [43] and enhance adaptability to local environmental and disease prevalent conditions [44].

Values for red blood cell showed significant difference $(\mathrm{p}<0.05)$ across treatments with the highest observed in $\mathrm{T} 3$ which was not significantly different from T2, but was significantly different from T1. RBC was $3.150-4.167 \times 10^{6} / 1$. This shows that birds fed ginger $1.0 \%$ had more red blood cells, which could imply that ginger have some innate quality to stimulate the production of red blood cells through vitamin synthesis. According to [40], red blood cell is involved in the transport of oxygen and carbon dioxide in the body. Thus, a reduced red blood cell count implies a reduction in the level of oxygen that would be carried to the tissues as well as the level of carbon dioxide returned to the lungs [40]. This implies that factors that promote the build-up of red blood cells should be encouraged. With PCV, Hb and RBC values being within normal ranges it could be said that the bone marrow of the bird was functioning normally thereby stimulating RBC formation. Mean cell volume (MCV) also showed significant difference at $p<0.05$. Range of values was $126.43 \mathrm{fl}-138.65 \mathrm{fl}$. Mean corpuscular haemoglobin $(\mathrm{MCH})$ also showed significant difference $(\mathrm{p}<0.05)$ with T1 having the least (42.44pg) while T3 had 48.19pg.Mean corpuscular haemoglobin concentration (MCHC) showed significant variation at $\mathrm{p}<0.05$. Highest level recorded was at $\mathrm{T} 3$ (1\% ginger) which from $\mathrm{T} 2(0.5 \%$ ginger) and $\mathrm{T} 1(0 \%$ ginger) which had $34.00 \mathrm{~g} / \mathrm{dl}$ and $33.55 \mathrm{~g} / \mathrm{dl}$ respectively. Observed range of values $(33.55 \mathrm{~g} / \mathrm{dl}$ to $34.18 \mathrm{~g} / \mathrm{dl})$ is similar to the normal range reported by [45]. Observed results for the differentials indicate that the inclusion of ginger at pharmaceutical levels did not alter the energy-protein balance in the diet. Results for haematological proteins (neutrophil and lymphocytes) showed significant difference $(\mathrm{p}<0.05)$ with T3 having significantly higher values $(\mathrm{p}<0.05)$ $(5.64,97.00)$ for neutrophil and lymphocytes respectively as compared to T2 and T1 $(4.58,96.55),(3.50,95.67)$ respectively. 
Iyaode et al. / GSC Biological and Pharmaceutical Sciences, 2020, 11(01), 197-206

Table 4 Effect of strain and treatment interaction on performance of broiler fed ginger

\begin{tabular}{llllllll}
\hline Parameters & T1S1 & T2S1 & T3S1 & T1S2 & T2S2 & T3S2 & LOS \\
\hline Initial weight (g) & $40.07 \pm 0.24$ & $40.06 \pm 0.24$ & $40.20 \pm 0.24$ & $39.77 \pm 0.24$ & $39.22 \pm 0.24$ & $39.26 \pm 0.24$ & NS \\
Final weight (g) & $484.00^{\mathrm{c} \pm 18.98}$ & $619.33^{\mathrm{a}} \pm 18.9$ & $645.33^{\mathrm{a}} \pm 18.98$ & $515.67^{\mathrm{c} \pm 18.98}$ & $583.33^{\mathrm{b} \pm 18.98}$ & $637.33^{\mathrm{a} \pm 18.98}$ & $*$ \\
Weight gain (g) & $444.52^{\mathrm{c} \pm 19.01}$ & $579.22^{\mathrm{a}} \pm 19.00$ & $605.89^{\mathrm{a}} \pm 19.01$ & $476.18^{\mathrm{c} \pm 19.01}$ & $543.84^{\mathrm{b} \pm 19.01}$ & $597.84^{\mathrm{a} \pm 19.01}$ & $*$ \\
Daily weight gain (g) & $15.88^{\mathrm{c} \pm 0.68}$ & $20.69^{\mathrm{a}} \pm 0.68$ & $21.64^{\mathrm{a} \pm 0.68}$ & $17.00^{\mathrm{c} \pm 0.68}$ & $19.42^{\mathrm{b} \pm 0.68}$ & $21.35^{\mathrm{a} \pm 0.68}$ & $*$ \\
Daily feed intake (g) & $65.36^{\mathrm{b} \pm} 1.59$ & $66.73^{\mathrm{b} \pm 1.59}$ & $69.45^{\mathrm{a} \pm 1.59}$ & $66.59^{\mathrm{b} \pm 1.59}$ & $65.57^{\mathrm{b} \pm 1.59}$ & $71.86^{\mathrm{a} \pm 1.59}$ & $*$ \\
FCR & $4.12^{\mathrm{c} \pm} \pm 1.00$ & $3.23^{\mathrm{a} \pm 1.00}$ & $3.21^{\mathrm{a} \pm 1.00}$ & $3.92^{\mathrm{c} \pm 1.00}$ & $3.38^{\mathrm{b} \pm 1.00}$ & $3.37^{\mathrm{a} \pm 1.00}$ & $*$
\end{tabular}

$\mathrm{abc}=$ means with different superscript along the same rows show significant different at $\mathrm{p}<0.05, \mathrm{LOS}=$ level of significance, NS = not significance, FCR $=$ feed conversion ratio, ${ }^{*}=$ significant.T $1(0 \%)=$ Treatment 1 of Basal diet, $\mathrm{T} 2(0.5 \%)=$ Treatment 2 containing $0.5 \%$ ginger and $\mathrm{T} 3(1.0 \%)=$ Treatment 3 containing 1.0\% ginger, S1 = Strain 1(Arbor acre), S2 = Strain 2 (Cobbs).

Table 4 shows that treatment and strain interaction had significant $(\mathrm{p}<0.05)$ effect on performance parameters, except initial weight. Observed results show T3S1 $(645.33 \pm 18.98)$, T3S2 (637.33 \pm 18.98$)$ and T2S1 (619.33 \pm 18.98$)$ being significantly higher as compared to the other treatment for final weight. The interaction of increasing inclusion of ginger with strain tends to significantly increase $(p<0.05)$ the final weight of the birds with higher inclusion of ginger irrespective of the bird strain. This is in contrast to report by [46] who reported the significant variation $(p<0.05)$ induced by strain effect in compensatory growth. Weight gain significantly varied $(p<0.05)$ due to diet and strain. Results obtained show significant higher value with increase in ginger inclusion in the diet for both strain.

A similar trend was obtained for daily weight gains. Values of result obtained were significantly increased $(\mathrm{p}<0.05)$ with increase in the inclusion level of ginger in the diet. Improvement in body weight gain of broiler chicks fed ginger might be due to the active components present in the ginger which stimulated digestive enzymes and improved overall digestion and thus led to increased body weight gain. It has been established that ginger in diet stimulated lactic acid bacteria and decreases pathogenic bacteria such as coliform and Escherichia coli and thus improved absorption of nutrients leading to better weight gain of the birds [46]. The results are consistent with those of [47]. Results indicate that less feed was consumed by the Cobbs strain compared to their Arbor acre counterpart. However, intake increased with the increasing inclusion level of ginger. This observation is in agreement with those of different workers who had earlier reported that ginger powder in broiler diet had a significant positive effect on feed consumption [5].

It was observed that $0.5 \%$ and $1 \%$ level of ginger inclusion significantly improved FCR which was more obvious in the Cobbs strain; thereby bringing about an increase in weight per unit of feed consumed. This further implies that a significant variation $(\mathrm{p}<0.05)$ is observed for treatment effect and not strain. Result obtained is in line with the report of [37]. The Authors worked on the effects of phytobiotic feed additives on different poultry species, and observed increased weight gain with significant reduction in feed intake, and improved feed conversion ratio when broilers were fed ginger diets as against the control diet.

Table 5 shows the interaction effect of strain and feed/treatment on the haematological indices of broiler chicken. There was significant difference $(\mathrm{p}<0.05)$ for strain effect and feed (ginger inclusion) on all the parameters evaluated except for the PCV. The trend of the result showed Cobbs strain had higher values for Hb and RBC. Birds showed significant increase $(\mathrm{p}<0.05)$ across treatment with increasing inclusion level of ginger for the parameters evaluated. Similar trends were observed with Arbor-acre which showed increased values for $\mathrm{WBC}, \mathrm{MCV}, \mathrm{MCH}, \mathrm{MCHC}$, neutrophils and lymphocyte as the inclusion level of ginger increased. Observed value of $9.38 \mathrm{~g} / \mathrm{dl}-10.90 \mathrm{~g} / \mathrm{dl}$ for haemoglobin in this study falls within the normal range for healthy chicken according to [42]. The haemoglobin count in this experiment indicates high efficiency of oxygen transportation, cellular metabolism and effective tissue respiration [48]. This corresponds with the report of [49], who opined that haemoglobin has the physiological function of transporting oxygen to tissues of the animal for oxidation of ingested food so as to release energy for the other body functions as well as transport carbon dioxide out of the body of animals.WBC ranged from 186.30 - 234.00. An increase in the WBC count suggests a severe microbial infection. This high WBC count may indicate disease presence, protective mechanism and provision of rapid and potent defense against infectious agents. However, the high percentage of the WBC may be associated with the ability of the strain of the broilers with the help of the feed (ginger) to perform well under very stressful conditions. The essential oil and oleoresin of Zingiber officinale exhibits significant antioxidant and antimicrobial activities [50]. 6Dehydroshogaol, 6-shogaol and 1-dehydro-6-gingerdione have been shown to be potent inhibitors of free radicals [51], this could explain the build-up of the white blood cell [45]. RBC is are very important in the transportation of oxygen from the lungs to the tissues and carbon(iv)oxide from the cell and tissues to the lungs for excretion. Though low, was 
adequate for the proper functioning of the birds [52]. Results showed that Hb, PCV and RBC were within the normal ranges for healthy birds. This may indicate proper synthesis of vitamin and optimal functioning of the bone marrow of the birds, in addition to significant effect of ginger on the haemoglobin and red blood cell, since haemoglobin functions as a carrier of oxygen to target organs by forming oxy-haemoglobin, a situation which indicates that the birds were not anaemic nor lacked oxygen[53].MCH and MCHC values found to be within normal ranges may indicate that feed formulation and compounding was well done without a negative interaction between energy and protein balance in the diet [45]. Neutrophils and lymphocytes showed significant difference $(\mathrm{p}<0.05)$ with Arbor Acre interaction, T3S1 having significantly higher values $(\mathrm{p}<0.05)$ (5.67) for neutrophil while Cobbs interaction T2S2 (97.91) had the highest significant value for lymphocyte. This implies the ability for healing of injuries, higher resistance or recovery to foot pad dermatitis and quick clotting of wounds increased with the increase of the inclusion levels of ginger in the diet as there was no allergic reaction to the treatment offered. [54] reported that apart from genotype, age, and sex, differences in haematological indices may be caused by nutrition.

Table 5 Strain and treatment interaction effect on the haematology of broiler chicken fed ginger (Zingiber officinale)

\begin{tabular}{|c|c|c|c|c|c|c|c|c|}
\hline Parameters & T1S1 & T2S1 & T3S1 & T1S2 & T2S2 & T3S2 & SEM & LOS \\
\hline $\operatorname{PCV}(\%)$ & 29.17 & 29.00 & 28.83 & 28.53 & 29.67 & 29.60 & 0.583 & NS \\
\hline $\mathrm{Hb}(\mathrm{g} / \mathrm{dL})$ & $9.48^{c}$ & $10.07^{b}$ & $10.17^{b}$ & $9.38^{c}$ & $9.98^{b}$ & $10.90^{\mathrm{a}}$ & 0.227 & $*$ \\
\hline $\mathrm{WBC}\left(\mathrm{x} 10^{9} / \mathrm{L}\right)$ & $213.67^{\mathrm{ab}}$ & $226.00^{\mathrm{a}}$ & $234.00^{\mathrm{a}}$ & $211.70^{\mathrm{ab}}$ & $186.30^{\mathrm{b}}$ & $231.40^{\mathrm{a}}$ & 15.339 & $*$ \\
\hline $\mathrm{RBC}\left(\mathrm{x} 10^{12} / \mathrm{L}\right)$ & $2.38^{\mathrm{b}}$ & $2.47^{a}$ & $2.52^{\mathrm{a}}$ & $2.41^{b}$ & $2.50^{\mathrm{a}}$ & $2.53^{\mathrm{a}}$ & 0.033 & $*$ \\
\hline $\operatorname{MCV}(\mathrm{fl})$ & $127.85^{b}$ & $131.32^{\mathrm{b}}$ & $140.02^{\mathrm{a}}$ & $125.02^{b}$ & $131.40^{\mathrm{b}}$ & $137.02^{\mathrm{a}}$ & 4.242 & $*$ \\
\hline MCH (pg) & $41.70^{\mathrm{b}}$ & $47.03^{\mathrm{a}}$ & $48.62^{\mathrm{a}}$ & $43.18^{b}$ & $42.93^{b}$ & $47.68^{\mathrm{a}}$ & 1.506 & $*$ \\
\hline MCHC (g/dL) & $33.65^{b}$ & $34.28^{a}$ & $34.40^{\mathrm{a}}$ & $33.45^{b}$ & $33.72^{b}$ & $33.92^{\mathrm{ab}}$ & 0.436 & $*$ \\
\hline Neutrophil $\left(\mathrm{x} 10^{9} / \mathrm{L}\right)$ & $4.17^{b}$ & $5.00^{\mathrm{ab}}$ & $5.67^{a}$ & $4.03^{b}$ & $4.17^{b}$ & $5.60^{\mathrm{a}}$ & 0.848 & $*$ \\
\hline Lymphocyte (x109/L) & $96.00^{a}$ & $96.83^{a}$ & $96.50^{\mathrm{a}}$ & $95.33^{b}$ & $97.17^{\mathrm{a}}$ & $96.60^{\mathrm{a}}$ & 0.861 & $*$ \\
\hline
\end{tabular}

\section{Conclusion}

From the result obtained, strain showed no significant effect $(\mathrm{p}>0.05)$ on the early performance and haematological indices of birds except for RBC, however, values of performance parameters obtained were significantly affected $(p<0.05)$ by the inclusion of ginger, as a consistent increase on the final weight, weight gain, daily feed intake and feed efficiency was observed with increase in the inclusion level of ginger in the diets of the broilers. Interaction effect of both strain and ginger showed significant effect $(\mathrm{p}<0.05)$ indicating the Cobbs strain as a better performer than Arbor acre. Haematological values of birds administered ginger at various level of inclusion showed better utilization of the experimental diets than control. Optimum haematological performance is achieved at an inclusion level of $1 \%$ in the diets of broilers. This tends to prove that the inclusion of ginger rhizome at $1 \%$ in the diets of the birds improved the health of the broilers. Thus for selection and effective utilization of feed, Cobbs strain at 1\% inclusion of ginger would stimulate an excellent haematological profile for optimum performance than Arbor acre. Based on the findings of this research, it is recommended that ginger be added at an inclusion level of $1 \%$ to diets of broiler for improved performance characteristics; also, the Cobbs strain should be used instead of the Arbor acre strain for better performance.

\section{Compliance with ethical standards}

\section{Acknowledgments}

The authors wish to acknowledge the managements of Kogi State University Anyigba and the staff of the Livestock Teaching and Research Farm, Kogi State University Anyigba. 


\section{Disclosure of conflict of interest}

The authors: Iyaode Iyekeji Ifelayo, Oyewole Benjamin Osigbodi, Adesola Mercy Adetola and Anjorin, Grace Oluwabunmi hereby declare that there is no conflict of interest.

\section{Statement of ethical approval}

The research was conducted in accordance with the ethical standard of the Institution.

\section{References}

[1] Agbakoba AM, Udealor A, Onwubu EC and Amalu CU. (1995). Evaluation of optimum supplementation level of poultry grower mash with sweet potato leaves in rabbit feeding. Proceedings of the 10 th Annual workshop on Animal Farming Systems, Research and Extension, January 29-February 3 1995, National Root Crop Research Institute, Umudike, Nigeria.

[2] Madubuike FN and Ekenyem BU. (2001). Non ruminant livestock production in the tropics. Gustchucks Graphics Centre, Owerri, Nigeria, 185.

[3] Adams C. (1999). Poultry and dietary acids. Feed International, 20(19), 1370-1372.

[4] Botsoglou NA. (2002). Effect of dietary oregano essential oil on performance of chickens and on iron induced lipid oxidation of breast, thigh and abdominal fat tissues. Poultry Science, 43, 223-230.

[5] Herawati M. (2011). The Effect of Feeding Red Ginger as phytobiotic on body weight gain, feed conversion and internal organs condition of broiler. InternationalJournal of Poultry Science, 10(12), 983-985.

[6] Sofowora A. (1993). Medicinal plants and traditional medicine Africa. Spectrum Books Ltd., 289.

[7] Schleicher A, Fritz Z and Kinal S. (1998). The use of some herbs in concentrates for broiler chickens]. Rocz. Nauk. Zootech, 25(3), 213-244.

[8] Bamidele 0 and Adejumo IO. (2012). Effect of garlic (Allium sativum L.) and ginger (Zingiber officinale Roscoe) mixtures on performance characteristics and cholesterol profile of growing pullets. International Journal of Poultry Science, 11(3), 217-220.

[9] Elagib HAA, El-Amin WIA, Elamin, KM and Malik HEE. (2013). Effect of dietary garlic (Allium sativum) supplementation as feed additive on broiler performance and blood profile. Journal of Animal Science Advances, 3, 58-64.

[10] Mmereole FUC. (2008). The Effects of Replacing Groundnut Cake with Rubber Seed Meal on the Haematological and Serological Indices of Broilers. International Journal of Poultry Science, 7(6), 622-624.

[11] Khan TA and Zafar F. (2005). Haematological Study in Response to Varying Doses of Estrogen in Broiler Chicken. International Journal of Poultry Science, 4(10), 748-751.

[12] Waugh DW, Considine DB and Fleming EL. (2001). Is stratospheric chlorine decreasing as expected? Geophys. Res. Lett, 28, 1187- 1190.

[13] Aderemi FA. (2004). Effects of replacement of wheat bran with cassava root sieviate supplemented or unsupplemented with enzyme on the haematology and serum biochemistry of pullet chicks. Tropical Journal of Animal Science, 7, 147-153.

[14] Ifatimehin 00, Musa SD and Adeyemi JO. (2011). Managing land use, transformation and land surface temperature change in Anyigba town, Kogi State, Nigeria. Journal of Sustainable Development in Africa,10(4), 106109.

[15] Deeb N and Lamont SJ. (2002). Genetic architecture of growth and body composition in unique chicken populations. J. Here, 93, 107-118.

[16] Gwaza DS, Noah ET and Wamagi TI. (2013). Discriminant analysis of morphological traits in selected population of the Tiv local chicken ecotype in the derived guinea savannah of Nigeria. Journal of Agriculture and Veterinary Science, 3(6), 60-74.

[17] Razuki WM, Mukhils SA and Hamad RF. (2007). Performance of three commercial Broiler strains reared under hot and thermoneutral conditions. Iraqi Journal of Agriculture, 12, 92-103. 
[18] Yalcin JP, Chen JL and Zhao GP. (2009). Comparative evaluation of three commercial broiler stocks in hot versus temperate climate. Journal of Poultry Science, 76, 921-929.

[19] Adebambo AO, Fagbenro Oland Fragite SO. (2005).Preliminary assessment of growth and reproductive data of three strains of chickens' broiler development in Nigeria. Proceeding of International Poultry Summit. Ota, Ogun State, 191.

[20] Baziz AH, Geraert PA and Padilha JCF. (1996). Chronic heat exposure enhances fat deposition and modifies muscle and fat partition in broiler carcasses. Journal of Poultry Science, 75, 505-513.

[21] Deeb N and Cahaner A. (2001). Genotype by environmental interaction with broiler genotype offering growth rate 1 . The effect of ambient temperature and naked neck genotype lines differing in genetic background. Journal of Poultry Science, 80, 695-702.

[22] Oladipo MF, Onimisi PA and Bawa GS. (2015). Response of broilers chicken fed diet containing Christmas bush (Alchornea cordifolia) seed meal. Proceeding 39th annual conference. Nigeria society of animal productionBabcock, Ogun State Nigeria, 398-402.

[23] Oguntoye MA, Bako J, Adamu F, Daniel DK, Daniel B and Joseph E. (2018). Effect of maize and yam peel based diet supplemented with xylanase, Amylase and Protease Multi-Enzymes on serum biochemistry and haematological indices of starter broiler chickens. Nigerian Journal for Animal Science,20(4), 355-363.

[24] Odunsi AA, Onifade AA and Babatunde GM. (1999). Response of broiler chicks to virginiamycin and dietary protein concentrations in the humid tropics. Arch. de Zootec, 48, 317-325.

[25] Durai PC, Maruthai TPT, Arumugam SS and Venugopal OA. (2012). Haematological Profile and Erythrocyte Indices in Different Breeds of Poultry. International Journal of Livestock Research, 2(3), 89-92.

[26] Oleforuh-Okoleh VU, Chukwu GC and Adeolu AI. (2014). Effect of ground ginger and garlic on the growth performance, carcass quality and economics of production of broiler chickens Global Journal for Bioscience and Biotechnology, 3(3), 225-229.

[27] Pourali M, Mirghelenj SA and Kermanshashi D. (2010). Effect of garlic powder on productive performance and immune response of broiler chickens challenged with Newcastle disease virus. Global Veterinaria,4, 616-621.

[28] Ali Aand Memon MS. (2008). Incorporation of Enteromorpha procera Ahlner as nutrition supplement in chick's feed. International Journal of Biological Biotechnology, 5 (3/4), 211-214.

[29] Al-Moramadhi SAH. (2010). The effect of Zingiber officinale roots infusion on some physiological parameters in broiler chickens. Kufa Journal for Veterinary Medical Sciences,1(2), 67-76.

[30] Amaduruanye W, Ikwunze K, Oguike MAand Onunkwo DN. (2018). Impact of ginger (Zingiber officinale) on intestinal, caeca microbial loads and growth performance of broiler. Nigeria Journal for Animal Science, 20(1), 123-133.

[31] Demir E. (2003). The use of natural feed additives as alternatives for an antibiotic growth promoter in broiler diets. British Journal of Poultry Science, 44, 44-45.

[32] Ademola SG, Farinu GO, Adelowo 00, Fadade MO and Babatunde GM. (2005). Growth performance antimicrobial activity of garlic and ginger mixture fed to broiler. Proceedings of the 2005 Nigerian Society for Animal Production, 71-74.

[33] Wadikar DD and Premavalli KS. (2011). Appetizer administration stimulates feed consumption, weight gain and leptin levels in male rats. Appetite, 57,131-133.

[34] Zomrawi WB, Abdel-Atti BM, Dousa DC and Mahala AG. (2012). The effect of ginger root powder (Zinzibal officenale) supplementation on broiler chicks' performance, blood and serum constituents. Online Journal of Animal and Feed Research, 1(6), 457-460.

[35] Onibi GE, Adebisi OE, Fajemisin AN and Adeyunji VA. (2009). Response of broiler chickens in terms of performance and meat quality to garlic (Allium Sativum) supplementation. African Journal of Agricultural Research, 4(5), 511-517.

[36] Fadlalla IMT, Mohammed BH and Bakhiet AO. (2010). Effect of feeding garlic on the performance and immunity of broilers. Asian Journal of Poultry Science, 4(4), 182-189.

[37] Windisch W, Schedule K, Plitzner C and Kroismayr A. (2008). Use of phytogenic products as feed additives for swine and poultry. Journal of Animal Science, 86, 140-148. 
[38] Onu PN. (2010). Evaluation of two herbal spices as feed additives for finisher broilers.Biotechnology in Animal Husbandry, 26, 383-392.

[39] Ramakrishna RR, Platel K and Srinivasan K. (2003). In vitro influence of spices and spice active principles on digestive enzymes of rat pancreas and small intestine. Nahrung, 47, 408-412.

[40] Isaac LJ, AbahG, Akpan B and Ekaette IU. (2013). Haematological properties of different breeds and sexes of rabbits. Proceedings of the 18th Annual Conference of Animal Science Association of Nigeria, 24-27.

[41] Togun VA, Oseni BSA, Ogundipe JA, Arewa TR, Hammed AA, Ajonijebu DC and Mustapha F. (2007). Effects of chronic lead administration on the haematological parameters of rabbits - a preliminary study. Proceedings of the 41st Conferences of the Agricultural Society of Nigeria, 341.

[42] Ahiwe EU, Emenalom 00, Etuk EB and Okehie UN. (2014). Performance of 'kaura' variety of sorghum (Sorghum bicolor) based diet supplemented with enzyme. Nigeria Journal of Animal Science,15(1), 75-82.

[43] Soetan KO, Akinrinde AS and Ajibade TO. (2013). Preliminary studies on the haematological parameters of cockerels fed raw and processed guinea corn (Sorghum bicolor).Proceedings of 38th Annual Conference of Nigerian Society for Animal Production, 49-52.

[44] Kabir M, Akpa GN, Nwagu BI Adeyinka IA and Bello UI. (2011). Sexual dimorphism, breed and age characteristics of rabbits in Zaria, Nigeria. Proceedings of the 16th Annual Conference of Animal Science Association of Nigeria, 133-137.

[45] Mitruaka BM and Rawnsley HM. (1977). Clinical Biochemistry and Haematological reference value in normal experimental animals publishing Inc, 106-112.

[46] Tekeli A, Kutlu HR and Celik L. (2011). Effect of Z. offincinale and propalis extracts on the performance, carcass and some blood parameters of broiler chicks. Current Research in Poultry Science, 1, 12-23.

[47] Sadeghi GH, Karimi A, Jahromi SP, Aziz T and Daneshmand A. (2011). Effect of cinnamon, thyme and turmeric infusions on the performance and immune response in of 1 to 21 day-old male broilers. Brazilian Journal of Poultry Science, 14(1), 15-20.

[48] Solomon MB, Campbel RG, Steele NC and Caperna TJ. (1991). Effects of exogenous porcine somatotropin administration between 30 and 60 kilograms on longissimus muscle-fiber morphology and meat tenderness of pigs grown to $90 \mathrm{~kg}$. Journal of Animal Science, 69, 641-645.

[49] Ugwene MC. (2011). Effect of dietary palm kernel meal for maize on haematological and serum chemistry of broiler turkey. Nigeria Journal of Animal Sciences, 13, 93-103.

[50] Bellik Y. (2014). Total antioxidant activity and antimicrobial potency of the essential oil and oleoresin of Zingiber officinale Roscoe. Asian Pacific Journal ofTropical Diseases, 4, 40-44.

[51] Shanmugam KR, Mallikarjuna K, Kesireddy Nand Sathyavelu RK. (2011). Neuroprotective effect of ginger on antioxidant enzymes in streptozotocin-induced diabetic rats. Food Chemistry and Toxicology, 49, 893-7.

[52] Olayemi FO, Alaka 00 and Sanni AA. (2002). Effects of infectious coryza disease in growing turkey on some erythrocyte parameters.African Journal of Biomedical Research,5, 83-86.

[53] Poole TB. (1978). UFAW hand book of care and management of laboratory animals $6^{\text {th }}$ edition.

[54] Chineke CA, Ologun AGand Ikeobi CON. (2006). Haematological parameters in rabbit breeds and crosses in humid tropics. Pakistan Journal of Biological Sciences, 9(11), 2102-2106.

\section{How to cite this article}

Iyaode II, Oyewole BO, Adesola MA and Anjorin GO. (2020). Performance and haematology of broiler strains (cobbs and arbor-acre) fed ginger (Zingiber officinale) based diet at the early phase. GSC Biological and Pharmaceutical Sciences, 11(1), 197-206. 